\title{
RAISING THE NEXT GENERATION FOR THE CHALLENGES OF BEING ORTHODOX \\ CHRISTIANS
}

\author{
Mark J. Cherry*
}

\begin{abstract}
This paper offers a conceptual geography of the collision between the centrality of the traditional Christian family, grounded in the Orthodox Church's knowledge and experience of God, and the banality of its secular counterpart. Christianity appreciates the family as created through the monogamous and life-long bond of the marriage of husband and wife, with the raising of properly Orthodox children as a central focus of family life. The dominant secular worldview of Western Europe and North America has brought this traditional understanding into question. For the secular world, the family is thought of as a self-pleasing social arrangement that expresses one's personal lifestyle choices. Such post-Christian families routinely encourage practices that Orthodox Christianity knows to be sinful, such as same sex marriage, cohabitation without marriage, abortion and surrogate motherhood. Emphasis is placed on developing children into self-possessed agents, who undertake their own moral and lifestyle decision-making as soon as possible. Children are taught to place financial and career success above cultivating a proper relationship with God. This is not a Christian understanding of proper childrearing, nor will such practices educate the young as Orthodox Christians. As this paper explores, Christians appreciate the family as the core community through which children learn how best to live and to seek salvation, as well as how properly to fulfill substantial duties to God, family members, and their community. The family is a sacramental relationship forged with the blessing of God and properly oriented towards Him.
\end{abstract}

Keywords: Orthodox Christian Family; Same-Sex Marriage; Abortion; Surrogate Motherhood

\section{Introduction}

Hear, O Israel, the Lord your God is one Lord; and you shall love the Lord your God with all your heart and with all your soul, and with all your might. And these words which I command you this day shall be

* PhD., Dr. Patricia A. Hayes Professor in Applied Ethics and Professor of Philosophy at St. Edward's University, Austin, Texas. 
upon your heart; and you shall teach them diligently to your children, and shall talk of them when you sit in your house, and when you walk by the way, and when you lie down, and when you rise (Deut. 6:3-7).

This admonition from Deuteronomy is a powerful reminder that parents, with the support of their families and the Church, have serious obligations carefully to nurture their children to submit to God and live fully Orthodox lives. This paper offers a conceptual geography of the collision between the centrality of the traditional Christian family, grounded in the Orthodox Church's knowledge and experience of God, and the banality of its secular counterpart. Christianity appreciates the family as created through the monogamous and life-long bond of the marriage of husband and wife, with the raising of properly Orthodox children as a central focus of family life. The dominant secular worldview of Western Europe and North America has brought this traditional understanding into question. For the secular world, the family is thought of as a self-pleasing social arrangement that expresses one's personal lifestyle choices. Such families routinely encourage practices that Orthodox Christianity knows to be sinful, such as same sex marriage, cohabitation without marriage, abortion and surrogate motherhood. Emphasis is placed on developing children into self-possessed agents, who undertake their own moral and lifestyle decision-making as soon as possible. Children are taught to place financial and career success above cultivating a proper relationship with God. This is not a Christian understanding of proper childrearing, nor will such practices educate the young as Orthodox Christians. As this paper explores, Christians appreciate the family as the core community through which children learn how best to live and to seek salvation, as well as how properly to fulfill substantial duties to God, family members, and their community. The family is a sacramental relationship forged with the blessing of God and properly oriented towards Him. 


\section{The Orthodox Home as a Small Church and the School of Christian Virtue}

The creation of a family through Christian marriage is a sacramental mystery. It is to be unique, monogamous, and holy ${ }^{1}$. The sacrament of marriage reveals God joining man and woman together into one flesh. Christ speaks directly to this point regarding marriage: And he answered and said to them, 'Ye read, did ye not, that the One Who made them from the beginning 'made them male and female,' and said, 'On account of this a man shall leave father and mother, and shall cleave to his wife, and the two shall be one flesh'? Therefore they are no longer two, but one flesh (Matth. 19: 4-6) ${ }^{2}$. This means, in part, that the union of husband and wife provides for the uniquely appropriate expression of sexual desire, as well as the proper union for the blessing and raising of children. Marriage is a serious and life-long endeavor.

As part of family life, Christians are called to raise godly children. As St. John Chrysostom summarized: Hear this, ye fathers bring up your children with great care in the nurture and admonition of the Lord.' (Eph vi)... Let us bestow great care upon them, and do everything that the Evil One may not rob us of them (St. John Chrysostom, 2004, Homily IX on 1 Timothy ii, 11-5, 436-7).

1 As St. Gregory Palamas (1296-1359) notes, “...God's law allows you to marry one woman and to live with her alone and to hold her in holiness as your own wife (cf. I Thess. 4:4), abstaining entirely from other women" $(1995,328)$. ${ }^{2}$ As St. John Chrysostom (347-407) emphasizes, the drive of men and women to marry and thereby to create a family is rooted in God's drawing of Eve from Adam: "For there is no relationship between man and man so close at that between man and wife, if they be joined together as they should be. ... For there is a certain love deeply seated in our nature, which imperceptibly to ourselves knits together these bodies of ours. Thus even from the very beginning woman sprang from man and afterwards from man and woman sprang both man and woman. Perceivest thou the close bond and connection? ... For there is nothing which so welds our life together as the love of man and wife" (St. John Chrysostom, Homily XXX on Ephesians, 2004, 143). 
Orthodox Christian families appreciate their lifeworld as properly communicating a normative form of social being, which is expressive of the proper contours of human flourishing and life in the Church. Christian families possess moral, historical, and metaphysical knowledge that children need. They are to nurture their children in the proper character and significance of the moral and spiritual life, about what one should do and why one should do it. Such knowledge changes the context and character of the family in the Church. Within the Orthodox Christian family, Children come to appreciate themselves as embedded in an ascetic and spiritual life. Overtime, they must come to understand that the most salient events in cosmic history are the Fall, the Incarnation, and the Redemption; that the universe was created by a Trinitarian God, and that humans are destined for immortal life.

Families are to be like a small church; they are to ... establish within the family truly Christian relationships, to raise children in faith and life according to the Gospel, to be an example of piety for those around one ... (Pomazanski, 1994, 302). The family is where children learn:

- piety (e.g., regular prayer and attendance at liturgy),

- spiritual discipline (e.g., keeping the Wednesday and Friday fasts, as well as the other traditional fast periods of the Church),

- proper virtue, such as humility (e.g., submitting to the authority of their parents),

- love (e.g., watching the love of their parents for each other and for their children),

- charity (e.g., realizing the need to take care of individuals other than themselves, such as brothers and sisters, parents and grandparents),

- moral medical decision making (e.g., abortion and euthanasia are deeply sinful acts),

- rightly oriented sexuality (e.g., parental instruction regarding the illicit nature of sexual activity outside of the marriage of 
man and wife),

- how to approach death (with humility and repentance, prayer and confession), and

- repentance (e.g., by seeking forgiveness from their parents for their poor behavior, and watching as their parents seek forgiveness from each other and from God) (see Cherry, 2016, p. 8).

The Christian family is the core community within the Church through which children learn how best to live, how to understand and to seek the good, as well as how properly to orient themselves towards God.

Consequently, parents ought actively to control access to education, media, and medicine, censoring choice of friends, associates, entertainment and lifestyle. The family's role in nurturing their children's intellectual and moral development is significant. Parents play an essential role in guiding and protecting their children during a period of intellectual, physical, emotional and spiritual development, when their decisional capacity is not yet that of a mature adult. Teaching young children and adolescents appropriate Christian discernment regarding good and evil is very challenging. There is, however, a considerable body of empirical data that demonstrates the positive impact of such authoritative parenting on the development of effective and appropriate adult decision-making (Wintre and Yaffe 2000; Slicker 1998). Children who grow up within traditionally Christian families, whose parents set clear expectations and boundaries, are benefited by these forms of nurturing. For example, such parenting improves the child's ability to resist harmful involvement, such as peer pressure and substance abuse (Adalbjarnardottir and Hafsteinsson, 2001). The home is the most powerful school of Christian virtue in the world, and it is here, in the Christian home, that children learn to shape their lives in submission to and love of God. 


\section{The Challenges of Secularism}

Outside of proper orientation towards God, the taken-forgranted moral and spiritual expectations of family life shift dramatically. If one thinks of the family as no more than a pleasing lifestyle choice, it becomes easy to affirm a wide-variety of family types, including homosexual unions, non-marital cohabitation, single parents, group living arrangements with open sexual practices, and so forth, as equally permissible. Many feminists, homosexual activists, and other defenders of post-traditional social structures support this post-traditional account of the family, seeking to liberate men, women, and children from what are appreciated as the confines of traditional religious norms. Such nontraditional accounts of the family and child rearing do not assume that parents ideally are married, share the same religion or lifestyle, or are of different sexes. In general, the demographic shift among adults is towards living together with a sexual partner without marriage or living as a sexually active single even without a live-in partner. An increase in the number of children born to single mothers is a predictable outcome of sexual activity outside of the traditional marriage of man and woman. As of 2012, Iceland was leading Europe with $66.9 \%$ of children born outside of marriage; Bulgaria was not far behind with $59.1 \%$, Estonia 58.4\%, Norway 55\%, and Sweden 54\%. For the twenty-eight member states of the European Union, the total percentage of children born out of wedlock was approximately $40 \%$ (Eurostat, 2015). In the United States, the statistics were very similar. In 2013, 40.6\% of all children were born to unmarried mothers (Martin et al., 2015). Secular culture has disconnected sex from marriage and traditional family life.

When many persons finally decide to have children, regardless of whether they marry, important other interests often interfere. There is real pressure, for example, to ensure that their offspring be free from any significant mental or physical disabilities. A disabled child, after all, would impact on career, lifestyle, and 
financial goals. This desire to give birth to a perfect and healthy child has pushed the boundaries of reproductive technology. Consider four brief examples of the clash between this secular ethos and Traditional Christianity.

- First, it encourages the use of abortion to choose when or if to have children. This includes, for example, prenatal diagnosis and selective killing in utero of children with a likelihood of significant disabilities. ${ }^{3}$ Denmark, for example, instituted routine prenatal screening for Down's Syndrome in 2006 as a public health initiative; other European countries, including France and Switzerland, followed. There is no way to cure Down's Syndrome; the only way to eliminate it from the population is to abort all children who test positive for Down's (Lindeman, 2015). Proponents portray such a disability as a tragic state that justifies termination of the pregnancy (Jesudason and Epstein, 2011, 541). There is no recognition of the sinfulness of abortion.

- Second, research teams have created human children with more than two parents. They have manipulated human embryos so as to substitute the original mother's mitochondria DNA with a donor female's mitochondria DNA. The goal is to generate human babies without mitochondrial defects, which are implicated in diseases such as multiple sclerosis and Parkinson's disease (Tachibana, Amato, Sparman et al., 2013; Tavare, e012; Baylis, 2013; Kouros, 2013). A child is created with two mothers and one

3 "Prenatal screening using non-invasive methods (e.g., ultrasound scanning, maternal serum screening) and genetic testing following invasive methods for obtaining fetal material (amniocentesis, chorionic villus sampling or fetal biopsy) to detect genetic conditions or fetal anomalies have become routine elements of reproductive medical care. They are framed as normative reproductive health practices allowing parents to avoid the birth of an affected child through 'therapeutic abortion,' or to prepare for the child's birth" (Kelly, 2009, 81). 
father. The mother who provides the ovum, the mother who provides the donor mitochondria, and the father who provides the sperm. Lost is any appreciation of the inappropriateness of bringing a third-party into the biological union of husband and wife.

- Third, assisted reproduction is required for homosexual and lesbian couples, as well as single women who want to reproduce. Access to assisted reproductive services, often at tax-payer expense, has been judged central to civil rights and moral equality ${ }^{4}$. Failure to provide such services to homosexual couples and single women is seen as unjust discrimination ${ }^{5}$. Civil rights law and court decisions have been specifically crafted to forbid Christians from refusing to assist homosexual couples and single women with fertility treatments on religious grounds ${ }^{6}$.

- Fourth, surrogate motherhood has become more socially acceptable. Couples are paying women to gestate and give birth to children on their behalf. Surrogacy contracts create

${ }^{4}$ The Ethics Committee of the American Society for Reproductive Technology concluded, for example, that fertility programs have an ethical duty to provide equal access to treatment for lesbian couples: "As a matter of ethics, this Committee believes that the ethical duty to treat persons with equal respect requires that fertility programs treat single persons and gay and lesbian couples equally to heterosexual married couples in determining which services to provide" $(2013,1526)$.

5 The American College of Obstetricians and Gynecologists asserted, for example: "Allowing physicians to discriminate on the basis of sexual orientation would constitute a deeper insult, namely reinforcing the scientifically unfounded idea that fitness to parent is based on sexual orientation, and, thus, reinforcing the oppressed status of same-sex couples" (2007; reaffirmed 2013).

${ }^{6}$ In 2008, the California Supreme Court ruled in North Coast Women's Care Group v. Benitez, $44 \mathrm{Cal}$. 4th 1145 (2008), that refusing to provide assisted reproductive medicine to a lesbian couple based on the physician's religious views violated state law. 
different types of arrangements for the production of children, such as (a) for the surrogate mother to be impregnated with the husband's sperm; (b) gestational surrogacy, in which the husband and wife create an embryo with their own sperm and ovum, but hire another woman to carry the child to term; (c) the use of donated embryos, or (d) the use of donor ova or donor sperm, and so forth. Clinics have been established to assist homosexual men to become parents ${ }^{7}$. The purchase of gestational services for the delivery of a healthy baby willfully sets aside the bonds of Christian marriage so as to reproduce in accordance with one's own particular lifestyle choices.

In short, children have become just another accoutrement of modern life. This is the cultural ethos that the secular world seeks to teach Orthodox Christian children.

Lost in this cacophony of medical technological choices is the Christian recognition that the union of husband and wife is the uniquely appropriate locus for reproduction, and that involvement of a third party in the reproductive relationship of husband and wife is a form of adultery. Everything, including the sexual union of husband and wife, as well as the conceiving and raising of children, is to be done in a way that is compatible with approaching holiness (Engelhardt, 2000, 235). Extra-marital partners, such as gamete and embryo donors or gestational carriers, should not be invited into the family. Moreover, it is not permissible to eliminate children from the family, when, through prenatal diagnosis, they are found to be imperfect ${ }^{8}$.

7 See http://Www.nwsurrogacycenter.com. Prospective parents can browse through their list of currently available surrogate mothers.

${ }^{8}$ As Engelhardt summarizes, The wife of the father of the child should be the mother of their child in the full sense. She should nurture their child in her womb. Motherhood may not be exported from marriage. A woman may not be involved in motherhood who is not the wife of the man whose child she is carrying (2000, 256). 


\section{Conclusions}

As illustrated, for the dominant secular culture of Western Europe and North American, family life and child rearing has become just another expression of a hedonistic and consumeristic culture. Once one abandons the traditional Christian experience of God and knowledge of His commands, each particular family is then guided by its own particular moral ethos. Without God, each family becomes its own experiment in living (Mill 1975, 70) ${ }^{9}$. It is a Babel. Orthodox Christians, however, know that all concerns of family life must be set within the pursuit of the kingdom of God. All elements of child-rearing, for example, from their conception, through raising them into adolescence and into adulthood, should be placed within the loving relationship of husband and wife and their love of God. Our families should direct significant energy to nurturing children, affirming the importance of salvation, love of God, and love of other family members, over self-satisfaction. Children should be taught Christian asceticism and almsgiving, rather than the pursuit of ever greater standards of living or the satisfaction of selfish desires. Career success should never be placed before love of God and family. Here, the family can be appreciated as a normative form of social being expressive of the proper form of human flourishing. In the Christian family, there is the recognition of the normative authority of a stable union of husband and wife, united in Holy Matrimony, with their children. The Christian family sets out a regulative ideal over against which actual instances of the family are measured and toward which families and their members are obliged

\footnotetext{
${ }^{9}$ John Stuart Mill argued in On Liberty: As it is useful that while mankind are imperfect there should be different opinions, so is it that there should be different experiments of living, that free scope should be given to varieties of character, short of injury to others; and that the worth of different modes of life should be proved practically, when anyone thinks fit to try them $(1975,70)$.
} 
to strive. We must with love carefully maintain our families, including children and grandchildren, fully within the lifeworld of Orthodox Christianity.

\section{References}

1. Adalbjarnardottir, S. and Leifur G. Hafsteinsson. 2001, Adolescents' Perceived Parenting Styles and Their Substance Use: Concurrent Longitudinal Analyses, in: "Journal of Research on Adolescence", 11 (4): 401-23.

2. American College of Obstetricians and Gynecologists. 2007. Committee Opinion No. 385. The limits of conscientious refusal in reproductive medicine. Obstetrics and Gynecology [On-line]. Available: www.acog.org/ResourcesAnd-Publications/Committee-Opinions/ Committee-on-Ethics/The-Limits-ofConscientious-Refusal-in-Reproductive-Medicine (accessed March 31, 2015).

3. Baylis, F. (2013), The ethics of creating children with three genetic parents, in: "Reproductive Biomedicine Online", 26:531-4.

4. Cherry, Mark J. (2016), Sex, Family, and the Culture Wars, New Brunswick: Transaction Publishers.

5. Chrysostom, John St. (1994), Homily IX on 1 Timothy ii, 11-5, in: Chrysostom: Homilies on Glatians, ephesians, Philippians, Colossians, Thessalonians, Timothy, Titus, and Philemon. Nicene and Post-Nicene Fathers, first series, volume 13, Philip Schaff ed. (435-437). Peabody: Hendrickson Publishers.

6. Chrysostom, John St. (2004), Homily XX on Ephesians, v. 22, in: Chrysostom: Homilies on Glatians, ephesians, Philippians, Colossians, Thessalonians, Timothy, Titus, and Philemon. Nicene and Post-Nicene Fathers, first series, volume 13, Philip Schaff ed. (143-152). Peabody: Hendrickson Publishers.

7. Engelhardt, H.T., Jr. (2000), The Foundations of Christian Bioethics, Salem, MA: Scrivener Publishing.

8. Ethics Committee of the American Society for Reproductive Medicine. (2013), Access to fertility treatment by gays, lesbians, and unmarried persons: A committee opinion, in: "Fertility and Sterility", 100:1524-7.

9. Eurostat. "Births, where the mother's marital status at the time of birth is other than married.

http://ec.europa.eu/eurostat/tgm/table.do? tab $=$ table\&init $=1 \&$ language $=e n \& p$ code $=$ tps00018\&plugin $=1$ (Accesed on July 20, 2015). 
10. Gregory Palamas, St. (1995), A New Testament Dialogue, in: G.E.H. Palmer, Philip Sherrard and Kallistos Ware (eds. And trans), The Philokalia, vol. 4 (323-330). London: Faber and Faber.

11. Jesudason, S. and J. Epstein. (2011), The paradox of disability in abortion debates: Bringing the pro-choice and disability rights communities together, in: "Contraception", 84: 541-3.

12. Kelly, S. E. (2009), Choosing not to choose: Reproductive responses of parents of children with genetic conditions or impairments, in: "Sociology of Health \& Illness", 31: 81-97.

13. Kouros, N. (2013), Britain set to be first to allow three-parent IVF, in: "Monash Bioethics Review", 31:24.

14. Lindeman, Renate. (2015), Down syndrome screening isn't about public health. It's about eliminating a group of people, in: "The Washington Post" (Accesed on June 16).

https://www.washingtonpost.com/posteverything/wp/2015/06/16/downsyndrome-screening-isnt-about-public-health-its-about-eliminating-a-group-ofpeople/

15. Martin, Joyce, A., Brady E. Hamilton, Michelle J. K. Osterman, Sally Curtin, T. K. Matthews. (2015), Births: Final Data for 2013, in: "National Vital Statistics Reports", 64 (1): 1-65.

16. Mill, J. S. (1975)., On liberty, in: "Three Essays", 5-144. New York: Oxford University Press.

17. Pomazanski, M. (1994), Orthodox Dogmatic Theology, Trans. S. Rose. Platina, CA: St. Herman of Alaska Brotherhood.

18. Slicker, Ellen K. (1998), Relationship of Parental Style to Behavioral Adjustment in Graduating High School Seniors, in: "Journal of Youth and Adolescence", 27 (3): 345-72.

19. Tachibana, M., P. Amato, M. Sparman, J. Woodward, D. M. Sanchis, H. Ma, N. M. Gutierrez, et al. (2013), Towards germline gene therapy of inherited mitochondrial diseases, in: "Nature", 493:627-31.

20. Tavare, A. (2012), Scientists are to investigate "three parent IVF" for preventing mitochondrial diseases, in: "British Medical Journal", 344:e540.

21. Wintre, Maxine Gallander and Mordechai Yaffe. (2000), First-Year Students' Adjustment to University Life as a Function of Relationships with Parents, in: "Journal of Adolescent Research", 15 (1): 9-37. 